\title{
PERBANDINGAN EFEKTIVITAS PASTA GIGI YANG MENGANDUNG SIWAK DENGAN PASTA GIGI TANPA SIWAK PADA PASIEN PASCA SKELING
}

\author{
${ }^{1}$ Eva A. Sijabat \\ ${ }^{2}$ Jimmy Posangi \\ ${ }^{3}$ Juliatri
${ }^{1}$ Kandidat Skripsi Program Studi Pendidikan Dokter Gigi Fakultas Kedokteran
${ }^{2}$ Bagian Farmakologi dan Terapi Fakultas Kedokteran
${ }^{3}$ Program Studi Pendidikan Dokter Gigi Fakultas Kedokteran
Universitas Sam Ratulangi Manado
E-mail: evaasijabat@yahoo.com

\begin{abstract}
Efforts to prevent gingivitis are indispensable; one of them is choosing toothpaste properly. Currently, many toothpastes are containing more than an active material. Additional of herbs in the toothpaste could hamper the growth of plaques. This study aimed to compare the effectiveness of siwak toothpaste and non-siwak toothpaste in reducing gingival index in post scalling treatment patients in Periodontology RSGM Sam Ratulangi University Manado. This was a randomized controlled trial group, which was performed to 30 patients. The subjects were divided into 2 groups: One group that used siwak toothpaste and another group that used non-siwak toothpaste. Gingivitis scoring was performed by using Gingival Index (GI) from Loe and Sillness on the day the patients got scalling treatment and then after two weeks. The collected data were analyzed by using Mann Whitney test. The results showed that there was a significant difference between using siwak toothpaste and non-siwak toothpaste in reduction the gingival index with a $\mathrm{p}$ value of $0.000(\mathrm{p}<0.05)$. Conclusion: There was a difference between the use of siwak toothpaste and non-siwak toothpaste in gingival index reduction in post scalling patients.
\end{abstract}

Keywords: toothpaste, siwak, non-siwak, gingival index

Abstrak: Upaya pencegahan terjadinya gingivitis sangat diperlukan. Hal yang dapat dilakukan antara lain dengan memilih pasta gigi yang tepat. Saat ini sudah banyak pasta gigi yang beredar dengan berbagai merek dan hampir semuanya mengandung lebih dari satu bahan aktif. Penambahan herbal pada pasta gigi dapat menghambat pertumbuhan plak penyebab terjadinya gingivitis. Penelitian ini bertujuan untuk mengetahui perbandingan efektivitas pasta gigi yang mengandung siwak dengan pasta gigi tanpa siwak pada pasien post skeling di Bagian Periodontologi RSGM Universitas Sam Ratulangi Manado. Desain penelitian ini ialah randomized controlled trial group terhadap 30 pasien pasca skeling. Subyek penelitian dibagi menjadi 2 kelompok yaitu kelompok penyikatan gigi dengan memakai pasta gigi siwak dan kelompok penyikatan gigi dengan memakai pasta gigi tanpa siwak.Penilaian indeks gingiva menurut Loe dan Sillness dilakukan setelah pasien gingivitis mendapatkan perawatan skeling dan dua minggu setelah pemakaian pasta gigi. Data yang diperoleh dianalisis menggunakan uji Mann Whitney. Hasil uji Mann Whitney menunjukkan bahwa terdapat perbedaan penurunan indeks gingiva yang bermakna antara penggunaan pasta gigi yang mengandung siwak dengan penggunaan pasta gigi tanpa siwak dengan nilai signifikansi $0,000(p<0,05)$. Simpulan: Terdapat perbedaan antara penggunaan pasta gigi siwak dengan pasta gigi tanpa siwak pada pasien post skeling.

Kata kunci: pasta gigi, siwak, tanpa siwak, indeks gingiva 
Gingivitis merupakan penyakit periodontal stadium awal berupa inflamasi gingiva pada jaringan lunak di sekitar gigi dan terjadi karena kebersihan mulut yang tidak memadai sehingga menyebabkan penumpukan plak dan kalkulus pada gigi. ${ }^{1}$ Upaya pencegahan terjadinya gingivitis sangat diperlukan, antara lain dengan menyikat gigi dua kali sehari dan memilih pasta gigi yang tepat.

Saat ini sudah banyak pasta gigi yang beredar dengan berbagai merek dan hampir semuanya mengandung lebih dari satu bahan aktif dan dipromosikan dengan beberapa keuntungan bagi pengguna. ${ }^{2}$ Penambahan herbal pada pasta gigi dapat menghambat pertumbuhan plak, karena beberapa jenis herbal memiliki kemampuan menghambat pertumbuhan mikroba. Bahan antimikroba pada ekstrak daun sirih dan siwak berperan sebagai bahan aktif dan mampu membunuh bakteri yang menjadi penyebab terbentuknya plak. Selain itu, karena herbal berasal dari tumbuhtumbuhan, maka bahan tersebut aman dan alami. $^{3}$

Siwak merupakan bagian dari batang, akar atau ranting tumbuhan Salvadora persica yang telah digunakan sebagai alat pembersih gigi dan mulut sejak 7000 tahun yang lalu. Siwak memiliki kandungan kimiawi dan beberapa mineral lainnya yang berfungsi membersihkan gigi, memutihkan, dan menyehatkan gigi dan gingiva. Menurut Lewis penelitian kimiawi terhadap tanaman siwak telah dilakukan sejak abad ke-19 dan ditemukan sejumlah besar klorida, fluor, trimetilamin dan resin. Hasil penelitian Farooqi dan Srivastava terhadap tanaman siwak ditemukan silika, sulfur dan vitamin C. Kandungan kimia tersebut sangat bermanfaat bagi kesehatan gigi dan mulut. Trimetilamin dan vitamin C membantu penyembuhan dan perbaikan jaringan gingiva. ${ }^{4}$ Menurut penelitianpenelitian tentang siwak terbukti bahwa penggunaan bahan siwak dapat membantu penyembuhan dan perbaikan jaringan gingiva. Berdasarkan uraian di atas, maka penulis tertarik untuk melakukan penelitian mengenai perbandingan efektivitas pasta gigi yang mengandung siwak dengan pasta gigi tanpa siwak pada pasien post skeling.

\section{METODE PENELITIAN}

Penelitian ini merupakan penelitian single blind, randomized controlled trial group pretest posttestdi Bagian Periodontologi Rumah Sakit Gigi dan Mulut Universitas Sam Ratulangi Manado pada bulan September-Oktober 2015. Populasi yang digunakan yaitu pasien pada Bagian Periodontologi Rumah Sakit Gigi dan Mulut Universitas Sam Ratulangi Manado. Sampel yang digunakan ialah pasien dengan kriteria inklusipasien yang menderita gingivitis marginalis kronis dan telah mendapat perawatan skeling dan telah menandatangani surat persetujuan penelitian (Informed Consent). Pasien yang memakai alat ortodontik dan tidak bersedia menjadi partisipan dalam penelitian ini dimasukkan ke dalam kriteria eksklusi. Besar sampel yang digunakan sebanyak 30 sampel yang mengacu pada besaran sampel minimal yang dapat digunakan dalam penelitian eksperimental sederhana. Pengambilan sampel pada penelitian ini menggunakan metode simple random sampling.

Pada penelitian ini peneliti melakukan pengukuran indeks gingiva awal pada subjek penelitian untuk mendapatkan data pretest dengan menggunakan probe periodontal. Indeks gingiva yang digunakan pada penelitian ini yaitu indeks gingiva menurut metode Loe dan Sillness, keempat area gingiva pada masing-masing gigi (fasial, mesial, distal dan lingual) dinilai tingkat inflamasinya dan diberi skor dari 03 (0, gingiva normal; 1 , inflamasi ringan pada gingiva yang ditandai perubahan warna, sedikit edema tetapi tidak ada perdarahan pada saat probing; 2, inflamasi gingiva sedang, warna merah, edema dan terjadi perdarahan pada saat probing; 3, inflamasi gingiva berat, warna merah terang, edema, ulserasi, kecenderungan adanya perdarahan spontan) serta ditentukan tingkat keparahan inflamasi gingiva. Skor $0=$ gingiva sehat, skor 0,1 $1=$ gingivitis ringan, skor $1,1-2=$ gingivitis 
sedang, skor 2,1-3 = gingivitis berat. Gingiva yang diperiksa ialah gingiva yang mengelilingi gigi 16, 21, 24, 36, 41 dan 44. Perdarahan dinilai dengan cara menelusuri dinding margin gingiva pada bagian dalam sulkus gingiva dengan probe periodontal. Setelah dilakukan pengukuran indeks gingiva, subjek yang termasuk kelompok uji diberikan pasta gigi yang mengandung siwak dan subjek lainnya yang termasuk kelompok kontrol diberikan pasta gigi tanpa mengandung siwak. Subjek diinstruksikan untuk menggunakan pasta gigi selama 2 minggu kemudian dilakukan pengukuran indeks gingiva terakhir pada 2 minggu berikutnya untuk mendapatkan data post-test. Data dikumpul, dilakukan perbandingan antara sebelum dan setelah penggunaan pasta gigi yang mengandung siwak dan pasta gigi tanpa siwak. Hasil pemeriksaan disajikan dalam bentuk tabel sehingga dapat dilihat perbedaan antara penggunaan pasta gigi yang mengandung siwak dan pasta gigi tanpa siwak.

\section{HASIL PENELITIAN}

Tabel 1 menunjukkan bahwa pada kelompok uji maupun pada kelompok kontrol terdiri dari responden laki-laki sebanyak 7 orang $(46,7 \%)$ dan responden perempuan sebanyak 8 orang $(53,3 \%)$.

Tabel 1. Distribusi frekuensi responden berdasarkan jenis kelamin pada kelompok uji dan kelompok kontrol

\begin{tabular}{ccccc}
\hline \multirow{2}{*}{ Jenis } & \multicolumn{2}{c}{ Kelompok } & \multicolumn{2}{c}{ Kelompok } \\
Kelamin & \multicolumn{2}{c}{ Uji } & \multicolumn{2}{c}{ Kontrol } \\
\cline { 2 - 5 } & $(\mathrm{n})$ & $(\%)$ & $(\mathrm{n})$ & $(\%)$ \\
\hline Laki-laki & 7 & 46,7 & 7 & 46,7 \\
Perempuan & 8 & 53,3 & 8 & 53,3 \\
\hline Total & 15 & 100 & 15 & 100 \\
\hline
\end{tabular}

terbanyak berusia 19 tahun berjumlah 4 orang $(26,7 \%)$ dan responden yang paling sedikit adalah responden dengan usia 15 , 17, 20, 21, 25, 26 dan 57 tahun yang masing-masing berjumlah 1 orang $(6,7 \%)$.

Tabel 2. Distribusi frekuensi responden berdasarkan usia pada kelompok uji

\begin{tabular}{ccc}
\hline Usia & $(\mathrm{n})$ & $(\%)$ \\
\hline 15 & 1 & 6,7 \\
17 & 1 & 6,7 \\
19 & 4 & 26,7 \\
20 & 1 & 6,7 \\
21 & 1 & 6,7 \\
22 & 2 & 13,3 \\
24 & 2 & 13,3 \\
25 & 1 & 6,7 \\
26 & 1 & 6,7 \\
57 & 1 & 6,7 \\
Total & 15 & 100 \\
\hline
\end{tabular}

Tabel 3 menunjukkan bahwa responden terbanyak berusia 19dan 22 tahun berjumlah 3 orang (20\%). Responden yang paling sedikit adalah responden dengan usia 16, 17, 23, 25 dan 26 tahun yang masing-masing berjumlah 1 orang $(6,7 \%)$.

Tabel 3. Distribusi frekuensi responden berdasarkan usia pada kelompok kontrol

\begin{tabular}{ccc}
\hline Usia & $(\mathrm{n})$ & $(\%)$ \\
\hline 16 & 1 & 6,7 \\
17 & 1 & 6,7 \\
19 & 3 & 20 \\
21 & 2 & 13.3 \\
22 & 3 & 20 \\
23 & 1 & 6,7 \\
24 & 2 & 13,3 \\
25 & 1 & 6,7 \\
26 & 1 & 6,7 \\
\hline Total & 15 & 100 \\
\hline
\end{tabular}

Tabel 2 menunjukkan responden

Tabel 4. Rerata indeks gingiva pada kelompok uji dan kelompok kontrol sebelum dan setelah penggunaan pasta gigi siwak pada kelompok uji dan pasta gigi tanpa siwak pada kelompok kontrol

\begin{tabular}{ccccccc}
\hline \multirow{2}{*}{ Kelompok } & \multirow{2}{*}{$\mathrm{N}$} & \multicolumn{2}{c}{ Sebelum } & \multicolumn{2}{c}{ Setelah } & Selisih \\
\cline { 3 - 6 } & & Rerata & Kategori & Rerata & Kategori & Rerata \\
\hline Uji & 15 & 1,22 & Sedang & 0,253 & Ringan & 0,967 \\
Kontrol & 15 & 1,246 & Sedang & 0,593 & Ringan & 0,653 \\
\hline
\end{tabular}


Tabel 4 menunjukkan bahwa terdapat perbedaan rerata indeks gingiva sebelum dan setelah menggunakan pasta gigi pada kelompok pasta gigi siwak dan pasta gigi tanpa siwak. Nilai rerata penurunan indeks gingivapada penggunaan pasta gigi siwak lebih besar yaitu 0,967 dibandingkan dengan nilai rerata penurunan indeks gingivapada penggunaan pasta gigi tanpa siwak yaitu 0,653. Berdasarkan kategori, penggunaan pasta gigi siwak memiliki efek yang sama dengan penggunaan pasta gigi tanpa siwak.

Tabel 5. Deskripsi skala numerik uji untuk kategori indeks gingiva

\begin{tabular}{ccccccc}
\hline Kelompok & Mean & Median & Range & Maximum & Minimum & $\begin{array}{c}\text { Std. } \\
\text { Deviation }\end{array}$ \\
\hline Uji & 0,967 & 0,900 & 0,5 & 1,2 & 0,7 & 0,1676 \\
Kontrol & 0,653 & 0,700 & 0,3 & 0,8 & 0,5 & 0,1302 \\
\hline
\end{tabular}

Tabel 6.Hasil uji Mann Whitney penurunan indeks gingiva antara kelompok uji dengan kelompok kontrol

\begin{tabular}{ccccc}
\hline Kelompok & N & Rerata & Selisih Rerata & Sig. \\
\hline Uji & 15 & 0,967 & \multirow{2}{*}{0,314} & 0,000 \\
Kontrol & 15 & 0,653 & & \\
\hline
\end{tabular}

Data pada Tabel 6 menunjukkan bahwa nilai signifikansi 0,000 atau kurang dari $0,05(\mathrm{p}<0,05)$ yang berarti bahwa $\mathrm{H}_{0}$ dalam penelitian ini ditolak dan $\mathrm{H}_{1}$ diterima. Berdasarkan hasil diatas maka dapat dinyatakan bahwa terdapat perbedaan penurunan indeks gingiva yang bermakna antara penggunaan pasta gigi yang mengandung siwak dengan pasta gigi tanpa siwak.

\section{BAHASAN}

Berdasarkan hasil penelitian pada Tabel 1 menunjukkan responden yang berjenis kelamin perempuan lebih banyak daripada responden yang berjenis kelamin laki-laki. Hal ini sejalan dengan penelitian yang dilakukan oleh Ni Made Windrawati ${ }^{5}$ mengenai gambaran perawatan gigi dan mulut pada bulan kesehatan gigi nasional periode tahun 2011 dan 2014 di RSGM Unsrat yang menyatakan perawatan gigi dan mulut lebih banyak pada perempuan dibandingkan dengan laki-laki. Pada penelitian lainnya yang dilakukan oleh Yohanes I Gede ${ }^{6}$ mengenai hubungan pengetahuan kebersihan gigi dan mulut dengan status kebersihan gigi dan mulut pada siswa SMA Negeri 9 Manado menunjukkan bahwa responden yang berjenis kelamin perempuan lebih memperhatikan kebersihan gigi dan mulutnya dibandingkan dengan responden berjenis kelamin laki-laki. Hal ini dapat disebabkan karena perempuan memiliki kecenderungan untuk lebih menjaga penampilannya termasuk kesehatan gigi dan mulut dari pada laki-laki.

Hasil penelitian pada Tabel 2 dan Tabel 3 menunjukkan bahwa umur responden mulai dari 15 sampai 57 tahun.

Berdasarkan hasil penelitian pada tabel 4 terlihat seluruh respondenpada kelompok uji maupun kelompok kontrol sebelum penggunaan pasta gigi memiliki indeks gingiva dengan kategori gingivitis sedang. Setelah penggunaan pasta gigi, seluruh responden pada kelompok uji maupun kelompok kontrol memiliki indeks gingiva dengan kategori gingivitis ringan.Tabel ini juga menunjukkan bahwa jumlah selisih rerata indeks gingiva sebelum dan setelah penggunaan pasta gigi pada kelompok uji lebih besar dibandingkan jumlah selisih 
rerata indeks gingiva pada kelompok kontrol dengan selisih rerata pada kelompok uji sebesar 0,967 sedangkan pada kelompok kontrol sebesar 0,653.

Berdasarkan hasil analisis uji Mann Whitney pada Tabel 6 menunjukkan bahwa terdapat perbedaan penurunan indeks gingiva yang bermakna antara penggunaan pasta gigi yang mengandung siwak dengan penggunaan pasta gigi tanpa siwak dengan nilai signifikansi $0,000(\mathrm{p}<0,05)$. Hal ini sejalan dengan penelitian-penelitian terdahulu mengenai efek klinis pasta gigi herbal dalam mengontrol gingivitis. ${ }^{7-9}$

Pada penelitian Ozaki et al. ${ }^{10}$ mengenai efektivitas penggunaan pasta gigi herbal pada pasien gingivitis disimpulkan bahwa pasta gigi herbal menunjukkan keuntungan dalam mengurangi klinis gingivitis secara bermakna dibandingkan dengan pasta gigi konvensional. Penurunan indeks gingiva juga dipengaruhi oleh kandungan siwak (Salvadora persica) pada pasta gigi siwak yang terdiri dari trimetyl amine dan vitamin $\mathrm{C}$ yang dapat membantu menyembuhkan jaringan gingiva. Trimetyl amine sendiri berfungsi dalam mengurangi kalkulus dan stain. ${ }^{11}$ Hasil penelitian ini juga sejalan dengan penelitian yang dilakukan Rahmah et $\mathrm{al}^{3}$ tentang perbandingan efektivitas pasta gigi herbal (siwak) dengan pasta gigi non herbal terhadap penurunan indeks plak pada siswa SDN Angsau 4 Pelaihari yang menyatakan terdapat perbedaan efektivitas pasta gigi herbal dengan pasta gigi non herbal terhadap penurunan indeks plak. Plak merupakan faktor yang paling dominan berhubungan dengan kejadian gingivitis. ${ }^{12}$

Pada penelitian ini pasta gigi yang mengandung siwak dapat menurunkan skor indeks gingiva dari kategori gingivitis sedang menjadi kategori gingivitis ringan. Hal ini sejalan dengan penelitian yang dilakukan Eid et al. ${ }^{13}$ tentang hubungan antara tanaman siwak dengan kesehatan periodontal menunjukkan bahwa penggunaan pasta gigi siwak dapat mengurangi gingivitis dan perdarahan pada probing.

Komposisi pasta gigi tanpa siwak pada penelitian ini antara lain: Calcium carbonate sebagai bahan abrasif, water sebagai bahan pelarut, sorbitol sebagai bahan pelembap, Sodium lauryl sulfate sebagai bahan deterjen, flavor, Cellulose gum, Pottasium citrate, Sodium silicate, Sodium saccobarin serta Sodium monofluorophosphate sebagai bahan fluoride yang dapat mencegah demineralisasi pada gigi sekaligus sebagai bahan aktif dalam pasta gigi tersebut. ${ }^{14}$

Penelitian ini menggunakan pasta gigi herbal dengan komposisi utama siwak dengan berbagai bahan tambahan lain, seperti Calcium carbonate sebagai bahan abrasif yang dapat membersihkan permukaan gigi tanpa merusak email, water sebagai bahan pelarut, sorbitol sebagai bahan pelembap, Sodium lauryl sulfate sebagai bahan deterjen yang dapat melonggarkan ikatan debris dengan gigi dan akan membantu gerakan pembersihan sikat gigi, Sodium carboxyl methyl cellulose, Fumed silicium dioxide, flavor peppermint, Sodium monofluorophosphate, Salvadora persica powder yang dapat membantu pembersihan sisa makanan pada sela-sela gigi, sodium saccharine, titanium dioxide, clove oil (Eugenia caryophyllus) dan metyl paraben. ${ }^{3}$

Pasta gigi siwak tetap dianjurkan untuk digunakan sebagai upaya tambahan kontrol gingivitis karena penggunaan pasta gigi yang mengandung siwak menunjukkan nilai indeks gingiva yang lebih baik dibandingkan dengan nilai indeks gingiva penggunaan pasta gigi tanpa siwak (Tabel 4). Hal ini yang mendorong perusahaanperusahaan pasta gigi di dunia menyertakan serbuk siwak ke dalam produk pasta gigi mereka. World Health Organization (WHO) turut menjadikan siwak sebagai salah satu komoditas kesehatan yang perlu dipelihara dan dibudidayakan. ${ }^{15}$

\section{SIMPULAN}

Dari hasil penelitian dapat disimpulkan bahwa rerata indeks gingiva sebelum menggunakan pasta gigi pada kelompok uji yaitu sebesar 1,22 sedangkan rerata indeks gingiva pada kelompok kontrol sebesar 
1,246. Rerata indeks gingiva setelah menggunakan pasta gigi pada kelompok uji yaitu sebesar 0,253 sedangkan rerata indeks gingiva pada kelompok kontrol sebesar 0,593 dengan selisih rerata 0,314 . Hal ini menunjukkan terdapat perbedaan antara penggunaan pasta gigi yang mengandung siwak dengan pasta gigi tanpa siwak pada pasien pasca skeling, dibuktikan dengan nilai signifikansi $\mathrm{p}=0,000(\mathrm{p}<0,05)$

\section{SARAN}

1. Penulis menyarankan penelitian ini dilanjutkan dengan waktu evaluasi dan jumlah sampelnya diperbanyak, guna memperoleh hasil penelitian yang lebih baik dalam pengamatan terhadap perbandingan efektivitas pasta gigi yang mengandung siwak dengan pasta gigi tanpa siwak terhadap indeks gingiva.

2. Penggunaan pasta gigi yang mengandung herbal disarankan untuk disebarluaskan sebagai alternatif dalam menurunkan akumulasi plak dan gingivitis, serta dapat dijadikan alternatif formulasi konvensional untuk individu yang tertarik pada produk alami.

\section{DAFTAR PUSTAKA}

1. Mariati NW, Hutagalung B, Lambe $H$. Status gingiva pada perokok di Desa Touliang Oki Minahasa. Dentire journal. 2013; 2(1):1.

2. Tampubolon SN. Dampak karies gigi dan penyakit periodontal terhadap kualitas hidup [Skripsi]. Medan: USU; 2005

3. Rahmah YR, Rachmadi P, Widodo. Perbandingan efektivitas pasta gigi herbal dengan pasta gigi non herbal terhadap penurunan indeks plak pada siswa SDN Angsau 4 Pelaihari. Dentino. 2014;2(2):120-4

4. Pratama RM. Pengaruh ekstrak serbuk kayu siwak (Salvadora persica) terhadap pertumbuhan bakteri Streptococcus mutans dan Staphylococcus aureus dengan metode difusi lempeng agar. Institut Teknologi Sepuluh Nopember [Skripsi]. [serial online] 2005. [cited
2015 Jun 18]. Available from: http://www.scribd.com/doc/43851437 /Pengaruh-Ekstrak-Serbuk-KayuSiwak\#scribd.

5. Windrawati NM, Mintjelungan C, Pangemanan DHC. Gambaran perawatan gigi dan mulut pada bulan kesehatan gigi nasional periode tahun 2011 dan 2014 di RSGM Unsrat. Jurnal e-gigi. 2015;3 (1):266-72

6. Gede YI, Pandelaki K, Mariati NW. Hubungan pengetahuan kebersihan gigi dan mulut dengan status kebersihan gigi dan mulut pada siswa SMA Negeri 9 Manado. Jurnal e-gigi 2013;1 (2):84-8.

7. Al-Kholani AI. Comparison between the efficacy of herbal and conventional dentifrices onestablished gingivitis. Dent Res J. 2011;8:57-63.

8. Pannuti MC, de Mattos JP, Ranoya PN, de Jesus AM, Lotufo RFM, Romito GA. Clinical effect of a herbal dentrifice on the control of plaque and gingivitis: a double blind study. Pesqui Odontol Bras. 2003;17:314-8.

9. Srinivasa S, Nandlal B, Srilatha K. A comparative evaluation of a commercialy available herbal and non-herbal dentrifice in dental plaque and gingivitis in children-a residential school based oral health programme. J Dent Oral Hyg. 2011;3:109-13.

10.Ozaki F, Pannuti CM, Imbronito AV, Pessotti W, Saraiva L, de Freitas NM, et al. Efficacy of a herbal toothpaste on patients with established gingivitis-a randomized controlled trial. Braz Oral Res. 2006; 20: 172-7.

11.Almas $\mathbf{K}$, Al-Zeid $\mathbf{Z}$. The immediate centimicrobial effect of a toothbrush and miswak on cariogenic bacteria: a clinical study. J contemp dent pract 2004;5 (1):1-8.

12.Hartati, Rusmini, Waluyo BT. Analisis faktor-faktor yang berhubungan dengan kejadian gingivitis pada ibu hamil di wilayah kerja Puskesmas Talang Tegal. Jurnal ilmiah kesehatan keperawatan. 2011;7(3):185.

13.Eid MA, Al-Shammery AR, Selim HA. The relationship between chewing sticks (miswak) and periodontal health. II. Relationship to plaque, 
gingivitis, pocket depth and attachmentloss. Quint int 1990;21: 1019-22.

14.Maldupa I, Brinkmane A, Rendeniece I, Mihailova I. Evidence based toothpaste classification, according to certain characteristics of their chemical composition. Stomatologija, Baltic dental and maxillofacial journal. 2012;14(1):12-22.

15.Ahmad $H$, Ahamed $\mathbf{N}$. Therapeutic properties of meswak chewing sticks: a review. African Journal of Biotechnology. 2012;11(83):14850-7. 